\title{
Green Marketing: A Study of Consumers' Attitude towards Environment Friendly Products
}

\author{
Jacob Cherian ${ }^{1} \&$ Jolly Jacob ${ }^{2}$ \\ ${ }^{1}$ Department of Management, College of Business Administration, Abu Dhabi University, Abu Dhabi, UAE \\ ${ }^{2}$ Department of Applied Sciences, College of Arts and Sciences, Abu Dhabi University, Abu Dhabi, UAE \\ Correspondence: Jolly Jacob, Department of Applied Sciences, College of Arts and Sciences, Abu Dhabi \\ University, Abu Dhabi, UAE. E-mail: jollyjacob70@hotmail.com
}

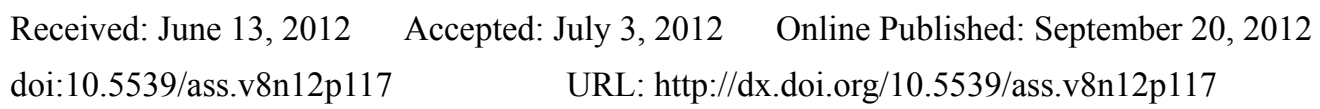

\begin{abstract}
Increasing awareness on the various environmental problems has led a shift in the way consumers go about their life. There has been a change in consumer attitudes towards a green lifestyle. People are actively trying to reduce their impact on the environment. However, this is not widespread and is still evolving. Organizations and business however have seen this change in consumer attitudes and are trying to gain an edge in the competitive market by exploiting the potential in the green market industry. The current study introduces the concept of green marketing and looks into the various ways in which the different consumer attributes are related to the concept of green marketing. A conceptual framework is presented and the information is analyzed on the basis of the framework.
\end{abstract}

Keywords: green marketing, green products, consumer attitude

\section{Introduction}

Today the concept of sustainability is almost ubiquitous by showing application in corporate strategy, consumer choice, student education and academic research. The need for sustainable business practices by corporations around the world is identified to be a result of overall increase in the consumer awareness of lack of environmental protection and social inequities. Over the last decade environmentalism has emerged to be a vital aspect due to increasing issues related to acid rains, depletion of the ozone layer, and degradation of the land and many more pressing environmental issues. This resulted in increase in consumer concern with regards to restoration of ecological balance by presenting demands for eco friendly products in countries around the world (Doyle 1992; Vandermerwe and Oliff 1990). The research on environmental consumerism is a well researched topic with the first research dating back to the 1970s (Henion and Kinnear, 1976). There has been extensive growth in interest exhibited by marketing academics as well as practitioners with regard to the impact of marketing on promoting and maintaining ecological balance (Chammaro et al., 2009; Bhattacharya, 2011). There is a great deal of depletion of non renewable energy resources which accompanied by generation of non bio degradable pollutants has lead to an increase in consumer and corporate awareness of green marketing issues.

The growth of green marketing research dates back to 1980s when there was emergence of concept of green marketing. Early literature indicates green marketing to be an approach which indicated signs of shift in consumer attention to green product. At that time green marketing research concentrated on the shift in consumer consumption of green products. There was a great deal of empirical research carried out to identify interest among consumers in using and purchasing green products (Mintel 1991). Green marketing approach was researched from a corporate interest point of view in the early $90 \mathrm{~s}$. Research indicated that $92 \%$ of MNCs from Europe changed their products to address growing concerns of environmental pollution. (Vandermerwe and Oliff, 1990). Green marketing research has come a long way since then. Consumers from the developed countries including USA and Western Europe were found to be more conscious about the environment (Curlo, 1999). Research in the last decade (Lee, 2009, Rahbar and Wahid, 2011, Lee 2008; D Souza 2004) has indicated that consumer are aware and are willing to pay more to "go green". There is limited research which has examined the impact of green marketing on consumers from emerging economies like India (Bhattacharya, 2011; Prakash, 2002).

Most of the studies related to green consumerism have been conducted in well developed countries. It is to be 
acknowledged that when considered from a developing country context there is a lack in number of studies. It is against this backdrop from the above discussion it is quite clear that there is a large research gap in terms conceptually identifying those areas of consumer awareness impacting the concept of green marketing.

\subsection{Aims}

The main objective of the current study is to understand the concept of Green marketing and to review some of the studies that have dealt with the concept of Green marketing and to identify the relationship between the various consumer attitudes and green marketing.

\section{Literature Review}

\subsection{Green Marketing and Green consumers}

Environmental marketing, more popularly known as green marketing or sustainable marketing can be defined as the effort by a company to design, promote, price and distribute products in a manner which promotes environmental protection (Polonsky, 2011). Green marketing has be defined as 'all activities designed to generate and facilitate any exchanges intended to satisfy human needs or wants such that the satisfaction of these needs and wants occurs, with minimal detrimental impact on the natural environment' by Polonsky (2011).

In this paper, green marketing covers the overall brand of marketing activities undertaken by companies in a manner that they promote manufacture of products which have a positive impact on environment or alternatively reduce negative impact on the environment. Today green marketing is a vital component of marketing research which began due to increasing media exposure and pressure on firms to present eco friendly behaviour. The growth in green marketing over the years has been promoted by adoption of product packaging and presenting to the public these improvements. Over the years there has been a subtle shift from practicing environmental marketing practices as a result of compulsion identified as a result of legislations and pressure from environmental groups to genuine efforts to improve sustainable marketing plans and behaving in an eco responsible manner (Polonsky and Rosenberger, 2001).

Consumerism can perhaps be identified as a movement which initially begun as a process which was presented to protect consumers against practices of unethical marketing. Over time this has extended and become broader in nature. When today's agenda with regards to consumer activism is taken into consideration it can be observed that protection of the environment is the most vital aspect (Dono et al., 2010). There is a resultant increase in the concern expressed towards environmental protection leading to "green consumerism" (Eriksson, 2002).

The growth of green marketing and green consumer is "perhaps the biggest opportunity for enterprise and invention the industrial world has ever seen" (Cairncross 1992: 177). A green consumer can be identified to be one who avoids any product which may harm damage to any living organism, cause deterioration of the environment during process of manufacturing or during process of usage, consume a large amount of non renewable energy, involves unethical testing on animals or human subjects (Elkington, 1994).

There have been a number of different factors which are instrumental in promoting green consumers to purchase green products. Extensive research over the years identify that heightened awareness of green issues; increased level of information availability on environmental sustenance; green advertising by corporations; increased concern for the environment; increase in popularity of green products by social and environmental charities as some factors. This overwhelming increase in the overall environmental consciousness among different consumer profile there have been efforts undertaken by firms to "go green" by presenting the concept of corporate environmentalism (Banerjee, 2003; Hay and Lichter 2000). Today green development are identified as opportunities by business firms as opportunities to improve their marketing niche rather than just actions which need to be carried out.

\subsection{Global Scenario in Green Marketing}

"Green' is the buzzword that is gaining popularity among the current generation. A number of businesses right from private entities such as Wal-Mart trying to push the concept of organic food to public entities like the London governments congestion charge are all aimed at improving the environment by promoting 'Green' products and issues. $87 \%$ of people from various nations like Brazil, Canada, China, France, Germany, India, the UK and the US have shown an interest in reducing their impact on the environment, according to a survey by (McKinsey, 2007). However, showing interest and actually acting on the interest are two different deeds. This fact is proved by a survey that was conducted on a global scale, which was repeated in 2008 with the help of BBC World, which showed that not a lot of people were actually doing something to move their lifestyle to a green lifestyle. 
The overall market for green marketing is said to be worth $\$ 3.5$ trillion by the year 2017 , according to a report by Global Industry Analysts Inc. of 2011. The report also states that increasing awareness about the environmental issues among the people, businesses and the governments is one of the main reasons for such market potential. Another research study by Mintel, clearly showed that $12 \%$ of the American population actively sought green products.

There is a growing need to switch over to green products and services by both marketers and consumers. Even though the shift to 'green' will be expensive to both the consumers as well as businesses, it will most definitely pay off in the long run. There are a number of literatures that focus on various aspects related to green marketing and also delves into the various inter relationships between the customers attitudes and environmental strategies in relation to the organizations use of marketing. Environmental issues are addressed in green marketing efforts. The core idea of green marketing is to create awareness among people on the environmental issues and how consumers would be helping the environment if they switch over to green products. Thus green marketing aims to provide more information to people and also gives those more choices to switch over to green lifestyle.

According to (Rex and Baumann, 2007), those aspects will spur businesses to develop more products from an environmentally friendly perspective. Green marketing is a part of marketing and therefore shares a number of aspects with traditional marketing such as price, promotions, products and place. Even green marketing requires that businesses develop and maintain a strong relationship with all their suppliers, their market intermediaries and significantly with the consumers, according to (Chan et al., 2012). A number of businesses have begun committing themselves to making their entire operation more environmentally friendly. Thus corporations are becoming more aware of their responsibilities towards the environment. This has forced the law makers, environment groups, consumers, financial institution, insurers and the organization's own employees to become more aware of environmental aspects and this in turn has led to an increase in the number of policies and schemes and regulations at both the national and international levels.

\subsection{The Attitude-Behavior Link}

It has always been believed by consumer behaviorists that an individual's actions can be predicted by their attitudes. There have been a number of attempts to improve the ability to predict an individual's actions and a variety of factors have also been suggested to involve factors which can be classified as either dispositional or situational. Spruyt (2007) indicate that prediction of behaviour is directly dependent on attitude of the consumer which is found to be associated with knowledge and personal experience they have (Davidson et al., 1985). The impact of beliefs and attitude on consumer buying habits has been studied extensively (Fazio and Zanna 1981; Ajzen 1989).

Furthermore research in this area has indicated that if attitudes are to be used in predicting the consumers behavior's then there are a number of methodological issues that have to be sorted out. According to (Ajzen and Fishbein, 1977), behavior and attitudes have to be measured at the same correspondence level.

There are a number of theories that have been put forth to explain the process by which attitudes predict behavior. According to (Ajzen and Fishbein, 1980, p. 5), theory of reasoned action, "people consider the implications of their actions before they decide to engage or not engage in a given behavior". Thus according to the above theory, people's attitudes play a significant role when it comes to their forming an intention to act in a certain behavior. The model primarily argues that people engage in processing that leads to the formation of attitudes, norms and intentions prior to performing the behavior.

However, the theory of reasoned action is not the only theory that deals with people's attitudes and behaviors. Fazio (1986), proposed another theory in which he states that "attitudes guide behavior through an automatic and spontaneous process instead of a deliberate one as argued by the earlier two theories". Furthermore Fazio (1989) also stated certain conditions in which behaviors and attitudes will be consistent. They are:

When the attitude influences perception. Thus when an individual forms a favorable (or unfavorable) attitude towards an object then the object will automatically be seen as one that has many favorable (or unfavorable) characteristics to the individual.

the attitude is accessed spontaneously by the mere presence of the object

In spite of the presence of theories that aid in prediction of behaviors from an individuals attitude, when it comes to environmental consumerism, the predictive ability of attitude is still being debated by researchers. There have been a number of attempts to provide a valid explanation to the presence of inconsistencies among behavior and attitudes, effects of external variables and lack of measurement reliability and validity (Mainieri et al., 1997), low correlations among environmental behaviors and different levels of specificity in the attitude behavior 
measures.

Previously done research studies have proven that there is no significant correlation between the pro environmental behaviors performed by an individual (Tracy and Oskamp, 1983-1984). Thus these studies showed that people who are into recycling may not be into carpooling. Therefore such inconsistencies exist because researchers tend to focus on a generalized view instead of measuring a specific behavioral aspect, according to (Mainieri et al., 1997). (Gadenne, 2011; Wulf and Schroder, 2003) recommended that in order to predict specific behaviors the attitudes measured have to be directed at a specific environmental issue like purchasing of green products. Furthermore, according to (Mainieri et al., 1997), the relationship between environmental attitudes and behavior may be confounded by situational factors (social norms, other attractive choices or economic constraints) and personal factors (knowledge, motivation or attitudes).

\section{Research Methodology}

The current research paper is a conceptual study in to green marketing. Therefore the researcher adopted a qualitative research strategy. According to (Ader et al., 2008), there are no independent or dependant variables involved in a qualitative study as a qualitative strategy is not experimental in nature. (Saunders, M, et al 2003), states that when it comes to conceptual research, it is important to review previously done researches on the same subject matter. A qualitative approach allows for an elastic process during which changes can be made and incorporated into the research. The current study does adopt a purely qualitative strategy as this research involves a dependent variable (Consumer perception of green marketing) and its impact on independent variable (attitude and behaviour towards green consumerism).

\section{Green Marketing: Consumer Attitude-Behavior Link}

\subsection{Consumer Attitude towards the Environment}

Environmental attitude is identified as the judgment an individual has towards the protection and promotion of the environment. Conflicting results have been published with regards to the relationship that currently exists between attitude towards the environment and the resultant behaviour (Kotchen and Reiling, 2000). There has been other empirical research which has concluded that the relationship is moderate at best (Davis, 1995). Green marketing depends on the consumer's attitude towards the environment. If there is no strong demand for such a shift in consumer attitude, businesses will not put in the extra effort to move towards introducing green products and services. Based on this evidence three different aspects can be arrived at in terms of identifying the relationship between environmental attitude and behaviour:

1) Need for more specific studies identifying the relationship between attitude and behaviour.

2) Need to identify other variables which have a mediating effect on both these attributes.

\subsection{Perceived Seriousness of Environmental Problems}

There have been a number of studies that have dealt with the topic of perceived seriousness of environmental problems. According to (Dunlap, 1994), most of these studies concentrated on determining the subjects view of the problem, its seriousness and how is differs from the numerous cultures. The studies found that some of the most common problems were air quality, sewage treatment and water quality. People living in the Asian nations were found to be more concerned with such problems when compared to their counterparts from other Western nations. One reason for this is that the Asian community tends to perceive their local communities in a negative manner than their Western or European counterparts (Dunlap, 1994).

In recent times a lot of attention has been paid to the effect that mass media has on the audience's perceived seriousness of environmental hazards. An example of one such study is the research done by Moser and Uzzell (2003). In that study, the authors stated that the audiences are influenced by the way the mass media interprets the pollution levels. A study on perception of environmental risks by (Bord and O'Connor, 1997) revealed that women were more perceptible to the risks involved in global warming and other related hazardous wastes when compared to the males. Furthermore the study also found that women were more worried about the various negative impacts that global warming could have on their health on their family's health. Businesses have started to understand consumer's attitude towards environmental problems and have therefore started to provide 'Green' products/services that provide an alternative to consumers. Green marketing is done by businesses to increase awareness levels and to show that people worried about the environment can do something to solve some of the issues.

\subsection{Perceived Environmental Responsibility}

According to a study by (Lai, 2000), the citizens of Hong Kong were found to be much more literate when it 
comes to issues regarding the environmental problems over the past few years. This clearly shows that people living in Hong Kong are more responsible when it comes to protecting their environment. However the study also determined that even though they were more aware of the problems their sense of individual duty towards taking corrective measures was significantly weak. On one hand they expected their government to take full responsibility of ensuring that all environmental related issues were solved through more proactive public policies and on the other hand they were not ready to follow through with the proposals that the government was suggesting in a bid to improve the environmental quality (Lai, 2000). Zelezny et al. (2000) have evidenced in their study that compared to males, females had higher levels of perceived personal responsibility towards environmental protection.

This difference in gender when it comes to the subject of environmental responsibility is explained mostly by the norm activation model that originated from the social psychology context (Schwartz, 1977). According to this model, most individuals are more likely to develop a helping behavior only when they become aware of the dangerous consequences that arise from global warming and when they actually feel responsible for their part in perpetuating this damage to the environment. In a sense, environmental behavior carries an altruistic meaning, whereby individuals may need to have a strong "other" orientation and willingness to sacrifice their time for preferred activities to protect the environment for the long-term benefits of the earth and human race. According to a study by (Gough, 1994), females tend to have a better ability to take control and take the responsibility for alleviating problems in the world and also they are the ones who have a stronger sense of ethics.

\subsection{Consumer Behavior towards Eco Labeling}

One important tool of green marketing involves the promotion of eco labels on environmentally friendly products (D Souza et al., 2006). Eco labeling is an effective measure which helps in bridging the gap between sellers and buyers by providing information on two aspects: Information function presenting intangible quality measures including product quality and Value function which presents the recyclability and CSR related brand prestige (Sammer and Wustenhagen 2006). Empirical research has concentrated on the need to look for ways by which eco labels will directly impact consumer purchase intention of products which are deemed to environmental safe (D Souza et al., 2006; Sammer and Wu"stenhagen 2006). There is a need to identify the impact eco labeling will have directly on the consumer environmental attitude in terms of decision making. The consumer awareness of eco labeling and its impact on consumer intent to purchase an eco friendly product has been researched and conflicting views have been expressed (D Souza, 2004; Rashid 2009; Lyer 1999).

Rashid (2009) has identified that when consumers are aware of eco labels they react more positively towards knowledge of green marketing and the purchase of green products. The research by Kuhn (1999) also adds value to his research by identifying that the promotion of eco friendly product manufacturing will definitely help improving a company's market share due to the ability of the company to present sustainable marketing strategies. Conflicting view was presented by Leire and Thidell (2005) who identified that consumer awareness of eco labeling does not necessarily lead to their green purchase decisions. This is further augmented by the research of Bleda and Valente (2008) indicated that eco labelling schemes have been linked to negative firm performance. D Souza (2004) on the other hand identified that there is not enough empirical evidence available to identify the relationship between the use of eco labels on products and its ultimate impact on eco friendly labels. The reason behind this maybe due to lack of trust among consumers (Lyer, 1999) with regards to the effectiveness of eco labels which is result of their ignorance of the concept of eco labeling.

The reason behind this consumer cognition has not been very well understood. Overall the understood perception is that eco labels are instruments which draw consumers by explaining their impact on the environment. The first eco labeling scheme Blue Anger eco label was introduced in Germany and today 30 different eco labeling methods are available. Countries in Asia have recently begun implementing labeling schemes which are uniquely their own as seen in India, Thailand, China and Japan.

\subsection{Consumer Behavior towards Environmental Advertisements}

Along with the process of labeling their products, arriving at measures which promote manufacturing of eco friendly products and reduction of environmental pollution there is a growing trend among corporations across the world to present environmental advertisements. This process is identified to be a major factor influencing green marketing. The main aim of presenting green advertisements is to present to the consumer that the company is eco centric while at the same time making an effort to influence the purchase behaviour of the consumers by presenting them with choices of availability of products which do not cause harm to the environment and directing their attention to positive consequences of purchase behaviour. There are three elements which form the core of environmental advertising. These include presentation of the corporation's 
mission statement with regards to environment protection, presentation of the procedures adopted by the company to go green and finally one specific CSR activity which has been adopted by the corporation (Davis, 1994). The creation of a consumer value and the subsequent translation into purchase of products is strongly identified by the impact of environmental advertisements (Baldwin, 1993).

As stated by Chase and Smith (1992), “environmental messages in advertisements and product labeling was found to 'sometimes' influence the purchasing decisions of 70 percent of the respondent. In the same study, more than half of the respondents indicated that they paid less attention to such messages due to excess usage, and most respondents reported that environmental advertisements were not credible". Chan (2004) states the main reasons for the low perceived credibility of environmental claims in environmental advertisement. The reasons are:

"The vague arguments to substantiate the environmental claim, the source country of the advertised product do not bear an eco-friendly image, the manufacturer (advertiser) of the advertised product does not bear an eco-friendly image and the alleged eco-friendliness of the advertised product does not match with the respondent's previous consumption experience" (p. 431).

Consumer behaviour towards pro-environmental marketing

The formation of attitude and action is found to be dependents on the development of values (Rokeach, 1973) however the impact these may have on behaviour in a real life condition. Thoughts (cognitive function) and feelings (affective function) are directly impacted by the attitude people show hence impacting their overall perception of purchase related behaviour (Hoyer and MacInnis, 2004). This identifies with the idea that there is a need to change the overall attitude consumers have towards a product thereby impacting their decision making. This scenario will apply to a green marketing context also. If one were to consider the Theory of Reasoned Action (Ajzen and Fishbein, 1980) into account then it can be postulated that marketers of green products change their method of evaluation of consumer attitude and intention to understand exactly what consumers really want. The new beliefs and normative beliefs of consumers can be identified in this manner.

An effective brand management strategy involves a principle wherein companies convert rational reasoning to emotional ones (Travis, 2000). If enough effort is taken by the brands then there should be a shift in consumer attitude towards suitable measures of sustainable consumption. It can be noted that if affective marketing concepts are promoted then it is possible to shift consumers who are passive towards concepts of "green" to active ones who are willing to go the extra mile and pay premium price in order to arrive at products which are pro environmental in nature thereby promoting effective green consumption behaviour (Ottman, 1998). A number of consumers have an ideal concept of being environmentally responsible but may not necessarily implement this concept thereby taking no efforts to move towards a lifestyle which is green. Thus any company which presents active measures of affective marketing may be supported by consumers as it presents an actual way of implementing the proposed concept as observed from the conceptual framework in figure 1.

There is not a lot of conclusive evidence on how the intention to buy can be developed under the context of environmental thinking and maintained within an integrated framework. Therefore the above framework strives to form a link between the consumer's attitudes and their behaviours in order to start the building process of environmental management towards green products. Thus the framework determines the relationships between consumer's attitudes and behaviour when it comes to the purchasing of green products. The concept of green marketing is still a new concept and it there are still far too much to be explored, according to First and Khetriwal (2008). However, a number of studies that have been mentioned above clearly indicate an increasing awareness among consumers on environmentally friendly brands and products. Brands have the capability to cause a change in consumer's attitudes. Similarly effective advertising strategies have the ability to cause a shift in consumers who are willing to pay a premium price for environmental products to green consumption patterns. 


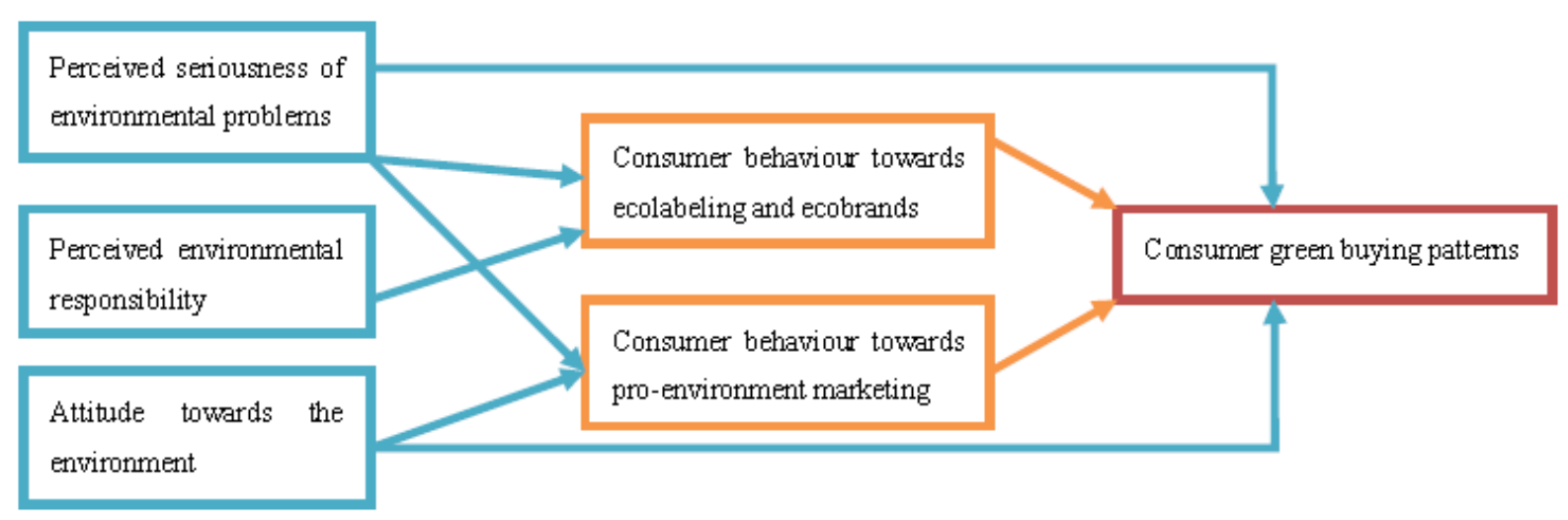

Figure 1. Conceptual framework

Lack of communication is considered to be a major reason for commercial failures of environmentally sustainable products mainly because communication is a major step in the development of a positive behaviour towards consumer's consumption patterns. A number of studies have dealt with the value perception of a specific set of environmental attributes. Moreover, previous researches carried out in western nations supported that consumers have positive green perceptions on eco-branded products. However a number of studies have also depicted that people tend to have a negative view towards green products that according to them shows a marked tradeoff between its effects on the environment and the functional performance of the brand. Emotional brand benefits can therefore be stated as being an important factor in encouraging consumers to alter their actual buying behaviours and purchase eco friendly items.

\section{Conclusion and Implications}

One thing that is being reiterated is that the current consumption levels are too high and are unsustainable. Therefore there is a need for green marketing and a need for a shift in the consumer's behavior and attitude towards more environmental friendly life styles. The current study is a compilation of various aspects related to green marketing. It is clearly evident from review of literatures and the conceptual model that the majority of the consumers still lack 'green' knowledge and because of such low awareness towards green products organizations are still not pushing towards developing more green products nor are they working hard on green packaging. Organizations still believe that marketing aspects such as developing a proper supply chain, packaging, pricing etc take precedence over green marketing initiatives. However, this is all changing. People are beginning to realize their role and responsibilities towards the environment. Although this change is not happening quickly, it is happening. Businesses are looking towards gaining an edge in the green market industry by trying to re-package their products into a more environmental friendly product. They are cutting down on extras and wasted materials and turning their operations into more efficient and green operation. Companies are also starting to educate the masses with an increase in advertising that puts emphasis on green products and how they are more beneficial for the consumers. This kind of advertising goes a long way in educating the masses and promoting the concept of green products among the people. With more and more consumers willing to pay a little extra towards green products, organizations are taking notice of the demands and behavior and attitude of the consumers.

\section{Recommendations}

Green marketing is a continuous process that requires constant inputs from the suppliers, government legislations and policies and the people. This is required so that the businesses green marketing strategy can be aligned to the target markets and so it can gain a sustainable competitive advantage. It is important that strategies and policies in relation to green products be developed and implemented so as to guide and help the retailers and customers towards a green change. Businesses should concentrate on focusing on developing a green product that have a demand from the general public and which also aligns to the company's core positioning. Furthermore businesses should also present efforts in a manner that reduces the risk related to costs. In conclusion, creating and implementing a green marketing strategy is not straight forward because it is not only complex, but also a relative concept that continuously varies over time.

The framework that is presented in the current paper is based on the need to explain inconsistencies in attitudes and behaviors that have been revealed in past researches. The current framework will be framing the gap between the attitudes and behaviors as a social dilemma and also attempts to understand the gap by trying to 
identify individual factors by using the reference group theory. Furthermore the framework also tries to recommend certain ways to cover the research gap. The current study will provide a valuable insight to both practitioners and theoreticians who want to understand environmentally conscious individuals. Since the success of green products depend on the consumers adopting or changing their attitude and behavior towards such products, it is imperative that green marketers identify all the factors that encourage cooperation. Thus the current study will also be of benefit to the green marketers as it aids in developing a marketing strategy that persuades consumers to seek the value of collective gain over self-interest.

\section{References}

Adèr, H. J., Mellenbergh G. J., \& Hand, D. J. (2008). Advising on research methods: A consultant 's companion. Huizen, The Netherlands: Johannes van Kessel Publishing.

Ajzen, I. (1989). Attitude structure and behavior. In Pratkanis, A. R., Breckler, S. J., \& Greenwald, A. G. (Eds.), Attitude, Structure and Function, Erlbaum. Hillsdale, NJ.

Ajzen, I., \& Fishbein, M. (1977). Attitude-behavior relations: a theoretical analysis and review of the research. Psychology Bulletin, 84, 888-918. http://dx.doi.org/10.1037/0033-2909.84.5.888

Ajzen, I., \& Fishbein, M. (1980). Understanding Attitudes and Predicting Social Behavior. Prentice-Hall, Englewood Cliffs, NJ.

Baldwin, P. (1993). Advertisers beginning to see green. The Dallas Morning News, p. J1-J11.

Banerjee, S. B., Iyer, E.S., \& Kashyap, R. K. (2003). Corporate Environmentalism: Antecedents and Influ-ence of Industry Type. Journal of Marketing, 67(2), 106-122. http://dx.doi.org/10.1509/jmkg.67.2.106.18604

Bhattacharya, Saurabh. (2011). Consumer Attitude towards Green Marketing in India. The IUP Journal of Marketing Management, 62-70.

Bleda, M., \& Valente, M. (2008). Graded eco-labels: a demand-oriented approach to reduce pollution. Technological Forecasting and Social Change, TFS-17065.

Bord, R. I., \& O'Connor, R. E. (1997). The gender gap in environmental attitudes: the case of perceived vulnerability to risk. Social Science Quarterly, 78(4), 830-840.

Cairncross, F., (1992). Costing the Earth: The Challenge for Governments, the Opportunities for Business. Boston: Harvard Business School Press.

Chamorro, A., Sergio Rubio, S., \& Miranda, Francisco J. (2009). Characteristics of Research on Green Marketing. Business Strategy and the Environment, 18, 223-239. http://dx.doi.org/10.1002/bse.571

Chan Hing Kai, He Hongwei, \& Wang William Y. C. (2012). Green marketing and its impact on supply chain management in industrial markets. Industrial Marketing Management, 41(4), 557-562. http://dx.doi.org/10.1016/j.indmarman.2012.04.002

Chan, R. Y. K. (2004). Consumer responses to environmental advertising in China. Marketing Intelligence \& Planning, 22(4), 427-437. http://dx.doi.org/10.1108/02634500410542789

Chase, D., \& Smith, T. K. (1992). Consumers keen on green but marketers don't deliver. Advertising Age, 63, 63.

Curlo, E. (1999). Marketing strategy, product safety, and ethical factors in consumer choice. Journal of Business Ethics, 21(1), 37-48. http://dx.doi.org/10.1023/A:1005973306941

D’Souza, C., Taghian, M., \& Lamb, P. (2006), An empirical study on the influence of environmental labels on consumers. Corporate Communication: An International Journal, 11(2), 162-173. http://dx.doi.org/10.1108/13563280610661697

Davidson et al. (1985). Amount of information about the attitude object and attitude behavior consistency. Journal of Personal and Social Psychology, 49, 1184-1198. http://dx.doi.org/10.1037/0022-3514.49.5.1184

Davis, J. J. (1995). Consumer response to corporate environmental advertising. Journal of Consumer Marketing, 11(2), 25-37. http://dx.doi.org/10.1108/07363769410058902

Dono, J., Janine, W., \& Ben, R. (2010). The relationship between environmental activism, pro-environmental behaviour and social identity. Journal of Environmental Psychology, 30(2), 178-186. http://dx.doi.org/10.1016/j.jenvp.2009.11.006

Doyle, J. (1992). Hold the Applause: A Case Study of Corporate Environmentalism. The Ecologist, 22(3), 84-90.

D'Souza, Clar. (2004). Eco-label programmes: a stakeholder (consumer) perspective. Corporate communications: 
An International Journal, 9(3), 179-188.

Dunlap Riley, E. (1994). International Attitudes towards Environment and Development. In Helge Ole Bergesen, \& Georg Parmann (Eds.), Green Globe Yearbook of International Co -operation on Environment and Development (pp.115-126). Oxford: Oxford University Press.

Elkington, J. (1994). Toward the Sustainable Corpor-ation: Win-Win-Win Business Strategies for Sustain-able Development. California Management Review, 36(2), 90-100.

Eriksson, C. (2004). Can green consumerism replace environmental regulation?-A differentiated-products example. Resource and Energy $281-293$. http://dx.doi.org/10.1016/j.reseneeco.2003.10.001

Fazio, R. H. (1989). On the power and function of attitudes: the role of attitude accessibility. In Pratkanis, A. R., Breckler, S. J., \& Greenwald, A.G. (Eds.), Attitude Structure and Function. Erlbaum, Hillsdale, NJ.

Fazio, R. H., \& Zanna, M. P. (1981). Direct experience and attitude-behavior consistency. In Berkowitz, L. (Ed.), Advances in Experimental Social Psychology (vol. 14). Academic Press, New York, NY.

First, I., \& Khetriwal, D. S. (2008). Exploring the relationship between environmental orientation and brand value: is there fire or only smoke? Business Strategy and the Environment. http://dx.doi.org/10.1002/bse.619

Gadenne, D., Sharma, B., Kerr, D., \& Smith, T. (2011). The influence of consumers' environmental beliefs and attitudes on energy saving behaviours. Energy Policy, 39(12), 7684-7694. http://dx.doi.org/10.1016/j.enpol.2011.09.002

Gough, H. G. (1994). Theory, development, and interpretation of the CPI socialization scale. Psychological Reports, 75(2), 651-700. http://dx.doi.org/10.2466/pr0.1994.75.1.651

Hay, B., Alexander, \& Mark A., Lichter. (2000). Strat-egies of Green Marketing, Retrieved from http://it.stlawu.edu/ advertiz/enviro/index.htm

Henion, K. E., \& Kinnear, T. C. (1976). Ecological Marketing, American Marketing Association. Chicago.

Hoyer, W., \& MacInnis, D. (2004), Consumer Behavior. Houghton Mifflin, Boston, MA.

Kotchen, M. J., \& Reiling, S. D. (2000). Environmental attitudes, motivations and contingent valuation of nonuse values: a case study involving endangered species. Ecological Economics, 32(1), 93-107. http://dx.doi.org/10.1016/S0921-8009(99)00069-5

Kuhn, G. L. (1999). Environmental labels and entry into an environmentally differentiated market under asymmetric information. Working Paper 20, Thunen Series of Applied Economic Theory, Universitat Rostock.

Lai, O. K. (2000). Greening of Hong Kong? Forms of manifestation of environmental movements. In Chiu, S. W. K. \& Lui, T. L. (Eds.), The Dynamics of Social Movement in Hong Kong (pp. 259-296). Hong Kong University Press, Hong Kong.

Lee, K. (2008). Opportunities for green marketing: young consumers. Marketing Intelligence \& Planning, 26(6), 573-586. http://dx.doi.org/10.1108/02634500810902839

Lee, K. (2009). Gender Differences in Hong Kong Adolescent Consumers Green Purchasing Behavior. Journal of Consumer Marketing, 26(2), 87-96. http://dx.doi.org/10.1108/07363760910940456

Leire, C., \& Thidell, A. (2005). Product-related environmental information to guide consumer purchases e a review and analysis of research on perceptions, understanding and use among Nordic consumers. Journal of Cleaner Production, 13(10), 61-70. http://dx.doi.org/10.1016/j.jclepro.2004.12.004

Lyer, G. (1999). Business, customers and sustainable living in an interconnected world: a multilateral ecocentric approach. Journal of Business Ethics, 20(4), 273-288. http://dx.doi.org/10.1023/A:1006095304996

Mainieri et al. (1997). Green buying: the influence of environmental concern on consumer behavior. Journal of Social Psychology, 137(2), 189-204. http://dx.doi.org/10.1080/00224549709595430

Mckinsey. (2007). Mckisey and Company Inc.

Mintel, R., \& Stamatiou, E. (2006). Green Roofs- A 21st Century Solution to the Urban Challenges of Green Space, Air Pollution, Flooding \& Energy Conservation, WSEAS International Conference Vouliagmeni, Greece. Journal WSEAS Transactions on Energy, Environment, Ecosystems and Sustainable Development, 
2(6), 909-918.

Moser, G., \& Uzzell, D. (2003). Environmental psychology. In Weiner, I., Millon, T., \& Lerner, M. (Eds.), Handbook of Psychology, Personality and Social Psychology (pp. 419-446). Wiley \& Sons, Inc., Hoboken, NJ.

Ottman, J. (1998). Green Marketing: Opportunity for Innovation. NTC-McGraw-Hill, New York, NY.

Polonsky, M. J., \& Rosenberger, P. J. III. (2001) Reevaluating green marketing: a strategic approach, Business Horizons, 44(5), 21-30. http://dx.doi.org/10.1016/S0007-6813(01)80057-4

Polonsky, M. J. (2011). Transformative green marketing: Impediments and opportunities. Journal of Business Research, 64(12), 1311-1319. http://dx.doi.org/10.1016/j.jbusres.2011.01.016

Prakash, A. (2002). Green Marketing, public policy and managerial strategy.

Rahbar, E., \& Wahid, N. A. (2011). Investigation of green marketing tools' effect on consumers' purchase behavior. Business Strategy Series, 12(2), 73-83.

Rashid N. A. (2009). Awareness of eco-label in Malaysia's green marketing initiative. International Journal of Business and Management, 4(8), 132-141.

Rex, E., \& Baumann, H. (2007). Beyond ecolabels: what green marketing can learn from conventional marketing. Journal of Cleaner Production, 15(6), 567-576. http://dx.doi.org/10.1016/j.jclepro.2006.05.013

Rokeach, M. (1973). The Nature of Human Values. The Free Press, New York, NY.

Sammer, K., \& Wüstenhagen, R. (2006). The influence of eco-labelling on consumer behaviour - results of a discrete choice analysis for washing machines. Business Strategy and the Environment, 15, 185-199. http://dx.doi.org/10.1002/bse.522

Saunders, M., Lewis, P., \& Thornhill, A. (2003). Research Methods for Business Students (3rd ed.). Harlow, Prentice Hall.

Schwartz, S. H. (1977). Normative influences in altruism. In Berkowitz, L. (Ed.), Advances in Experimental Social Psychology (vol. 10, pp. 221-279). Academic Press, New York, NY.

Spruyt, A., Hermans, D., Houwer, J. D., Vandekerckhove, J., \& Eelen, P. (2007). On the predictive validity of indirect attitude measures: Prediction of consumer choice behavior on the basis of affective priming in the picture-picture naming task, Journal of Experimental Social Psychology, 43(4), 599-610.

Tracy, A. P., \& Oskamp, S. (1983-1984). Relationships among ecologically responsible behaviors. Journal of Environmental Systems, 13(2), 115-126.

Travis, D. (2000). How Successful Brands Gain the Irrational Edge: Emotional Branding. Prima Publishing, Washington, DC.

Vandermerwe, S., \& Michael, D. O. (1990). Customers Drive Corporations Green. Long Range Planning, 23(6), 10-16. http://dx.doi.org/10.1016/0024-6301(90)90096-M

Wulf, K. D., \& Schröder, G. O. (2003). Assessing the impact of a retailer's relationship efforts on consumers' attitudes and behavior. Journal of Retailing and Consumer Services, 10(2), 95-108.

Zelezny, L., Chua, P., \& Alrich, C. (2000). Elaborating on gender differences in environmentalism. Journal of Social Issues, 56(3), 443-457. http://dx.doi.org/10.1111/0022-4537.00177 